\title{
Omvårdnadsutbildning som mål eller medel? \\ Om legitimitetsproblem och kunskapssyn.
}

PETRA AHNLUND \& STINA JOHANSSON

Utbildning och kompetens för omsorgspersonal är aktuella frågor som diskuteras på olika samhällsnivåer. Artikeln behandlar hur enhetschefer och personal på några äldreoch handikappomsorgsenheter förhailler sig till dagens formella utbildningskrav och vad man anser är relevant kompetens för att arbeta inom omsorgens verksamheter.

\section{Inledning}

Omsorgsarbete presenteras på central myndighetsnivå som ett komplext arbete där personalen behöver särskild kompetens. För äldreomsorgen är utbildnings- och kompetensfrågor högaktuella teman som uppmärksammas av centrala aktörer (se t.ex. Prop. 2005/06:115, Socialstyrelsen 2002, 2004, Svenska Kommunförbundet 2003). Enligt Socialstyrelsen (2002) är kompetensförsörjning den viktigaste frågan för

Petra Ahnlund, doktorand, institutionen för socialt arbete, Umeå universitet.

Stina Johansson, professor, institutionen för socialt arbete, Umeå universitet. att säkra god kvalitet i omsorgen om äldre, något som även vård- och äldreomsorgsminister Ylva Johansson instämmer i då hon menar att med kompetenshöjning följer en bättre kvalitet i äldreomsorgen (Kommunalarbetaren 2006). Lägsta nivå på den formella utbildningen definieras enligt Socialstyrelsen (2001) som vård- och omsorgsutbildning motsvarande gymnasiekompetens. Bemötandeutredningen som kom 1997, anser det inte tillräckligt med ovanstående kompetenskrav. Personalen behöver minst grundutbildning enligt gymnasieskolans omvårdnadsprogram samt fördjupningskurser och specialisering inom relevanta områden (SOU 1997:51). Det innebär att 
all personal bör ha minst undersköterskekompetens. Det är en rekommendation Socialstyrelsen står fast vid. I utredningen „Investera nu'» påtalas att all omvårdnadspersonal, omfattande baspersonal inom både äldre- och handikappomsorgen, bör ha kunskaper inom pedagogik, medicin samt det sociala fältet som grund för sin yrkeskompetens och att dessa kompetenser bör utvecklas genom gymnasieskolans omvårdnadsprogram (Socialstyrelsen 2004). Samtidigt är andra satsningar aktuella, bl.a. Kompetensstegen, som syftar till att stödja kommunernas kvalitets- och kompetensarbete för vård och omsorgspersonal inom äldreomsorgen (S 2004:10).

På kommunal nivå, där man ska rekrytera personal till fungerande verksamheter för arbete i direkt kontakt med äldre och funktionshindrade, har man delvis andra utgångspunkter i sin bedömning av kompetenskrav och utbildningsbehov. I vårt empiriska material är det tydligt att svenska chefer på lokal nivå ger uttryck för en ambivalens inför vad de anser vara den bästa kompetensen (Johansson 2003). ${ }^{1}$ De pekar på ett sug efter kompetensutveckling hos personalen, samtidigt som de framhåller att det är viktigare med praktisk erfarenhet än

1 Artikeln baseras på material insamlat i ett EUfinansierat projekt: „Care Work in Europe. Current understandings and future directions", med datainsamling i sex europeiska länder. Projektet omfattar olika yrkesgrupper i äldre- och handikappomsorgen. I denna artikel ingår intervjumaterial med omsorgspersonal och enhetschefer från Sverige. Artikeln ingår som en del i huvudförfattarens (Petra Ahnlunds) avhandlingsarbete om omsorgspersonal och upplevelser av arbetet. med formell utbildning. Det kan vara enklare att få till stånd det ömsesidiga utbytet om man har erfarenhet av att sköta ett hem eller inte är för ung.

Högre chef $i$ kommun: (...) i mötet mellan en äldre person, pensionären och en riktigt ung, flicka eller pojke som kommer, nog kan det också fungera, men rent generellt kan det vara enklare att få till stånd det där samtalet och erfarenhetsutbytet om man kommit en bit $i$ livet. (Johansson 2003:108. Urspr. lydelse)

Från andra undersökningar framgår att även vårdbiträden hävdar att erfarenheten är kärnan i deras yrkeskunskap, och att den är tillräcklig för att de ska kunna utöva sitt yrke (Wahlgren 1996, Wreder 2005). Personalen ser inget behov av att verbalisera vad de gör, eftersom arbetet styrs av de äldres behov och hur den äldre vill att arbetet ska utföras (Christensen 1997).

Det finns skillnader mellan hur utbildning och kompetensfrågor behandlas inom äldre- och handikappomsorgen. Som vi visat ovan är äldreomsorgens personal i fokus vad gäller aktuella satsningar för kompetenshöjning. I äldreomsorgsforskningen har det under en lång tid förts diskussioner kring personalens kompetensnivå och huruvida det ska ställas formella utbildningskrav för omsorgsarbete eller inte. Flera nya avhandlingar fokuserar på frågor kring utbildning och kompetens (Astvik 2003, Drugge 2003, Törnquist 2004). Inom handikappomsorgsforskningen är frågan om utbildning och kompetensutveckling inte lika uttalad eller problematiserad. Flertalet avhandlingar handlar om vardagslivet för människor med 
funktionshinder i den kommunala omsorgen och dessa studier inkluderar även personalens förhållningssätt till sitt arbete (se t.ex. Mallander 1999, Olin 2003, Sauer 2004). Ett fåtal studier berör utbildning för personliga assistenter (se t.ex. Socialstyrelsen 2005a) men i jämförelse med äldreomsorgens aktuella debatt kring utbildning och kompetensfrågor, saknas inom handikappomsorgen enskilda studier kring dessa teman. Vi menar att det finns en levande diskussion även bland enhetschefer och personal inom handikappomsorgen vad gäller utbildning och kompetensfrågor som vi i denna artikel vill belysa.

De motstridiga uppfattningar vi hittills presenterat angående hur olika aktörer i äldreomsorgen ser på formell utbildning och den ojämna fokusering för dessa frågor i äldre- respektive handikappomsorgen, har väckt vårt intresse för att analysera vilken betydelse begrepp som kompetens och formell utbildning har för personal som arbetar inom äldre- och handikappomsorgen. Syftet med artikeln är att analysera och diskutera hur enhetschefer och personal kan resonera kring omsorgspersonals utbildning och kompetens i relation till den verksamhet de arbetar inom och de uppgifter de utför.

I analysen och diskussionen kommer vi att använda Abbotts (1988) professionsteori, som på många sätt skiljer sig från andras genom att sätta processer på arbetsplatsen i förgrunden. Att kontrollera och bevaka arbetsuppgifterna brukar ingå i en professions kultur. Professionsforskare har ägnat mycket kraft åt att studera en yttre organisering för att göra demarkationslinjen till andra yrken tydlig. Abbott menar att "1... relatively less organized professions have certain distinct advances in workplace competition. Because they lack a clearly established cognitive structure, they are free to move into available tasks" (s. 83).

Hur kunskap appliceras i praktiken, hur legitimitet skapas för den i det kulturella sammanhang som arbetsplatsen utgör, blir således en utmaning att studera inom ett yrke där formalisering av behörighetskrav inte uppstått i en konkurrens om uppgifter, utan varit något som krävts utifrån.

\section{Utbildning som professionaliseringsstrategi}

Utbildning, kunskap och kompetens är begrepp som teoretiskt har behandlats inom professionsteorin. Kunskapsbasen är av stor betydelse för en yrkesgrupp. Ofta tar yrkesgruppen själv ansvar för att medlemmarna har utbildning upp till en viss nivå och också för att saluföra sin yrkeskunskap. Så förhåller det sig inte i de yrkesgrupper vi här presenterar. Deras utbildning och kompetens har i stället bestämts av yttre krav och förväntningar (Socialstyrelsen 2005b). Vi tror ändå att några av de begrepp som utvecklats inom professionsteorin kan vara användbara för att analysera utsagorna om kompetenskrav i arbetet från omsorgspersonal och deras arbetsledare.

Ett sätt att tänka kring kunskap och kompetens är att se den i relation till yrkesgruppens egna intressen. Abbott (1988) använder sig av begrepp som abstraktion och legitimitet för att beskriva kunskapens funktion. Abstraktionen - att man kan tala om det man gör - kan användas för att argumentera för en plats på arbetsmarknaden, 
ofta för att stärka den. De begrepp man då använder ska tydliggöra att man behärskar något som det inte är allom givet att förstå. Detta ger legitimitet åt yrket.

Att framgångsrikt kommunicera med omvärlden är nödvändigt och till gagn för yrket. Trots att Abbott inte diskuterar kunskapsbasen hos yrken utan hos professioner, ska vi ändå använda oss av hans begrepp för att analysera utsagor om utbildning och kompetens. Framför allt ska vi ägna oss åt det som Abbott ser som abstraktionens begränsningar. Han menar att om kunskapen i kommunikation med andra presenteras så generellt att den sammanhållande idén inte är tydlig, försvagas yrkesgruppens position. Om yrkesföreträdaren inte kan förklara hur yrkeskunskapen korresponderar med centrala värden i den kringliggande kulturen, i detta fall arbetsplatsen, försvagas alltså argumenten för denna. Abbott nämner två sådana abstraktionsformer. Den ena formen av abstraktion leder till brist på konkret innehåll. Man talar om ett arbetsinnehåll utan att det går att visa på effektiva praktiska resultat, försvagar dess betydelse. "With no effective treatments, abstractions are simply generalities without legitimacy" (s. 103). Den andra formen av abstraktion betonar formalisering, där kunskapens användning begränsas till ett mindre område och kräver specifik kompetens. Ofta sammanfaller de båda typerna, men de måste ändå hållas isär menar Abbott (1988). Abstrahering i den första meningen - brist på innehåll - kan göra yrket svagt eftersom det inte finns något klart samband mellan en insats och ett resultat. Då kan var och en få intrycket att vem som helst kan utföra dessa arbets- uppgifter. Yrkesgruppens legitimitet försvagas då fältet under dessa förhållanden står öppet för andra att etablera sig på. Abstrahering i den andra meningen - formalisering (s.102) - kan komma att stärka yrket, särskilt om kopplingarna mellan insats och resultat är starkt. Sett till den medicinska diskursen är framgången associerad med effektiv behandling. Om däremot formalisering sker utan en sådan effektivitet, kan det innebära en försvagad tilltro till yrket. Abbott (1988) ger exempel från företagsekonomi (business management s.103) där en sådan effektivitet inte kan påvisas.

I förhållande till de verksamheter vi studerar har yttre tryck lett till förändringar i både äldreomsorg och omsorg om funktionshindrade. De politiska målen har hävdats mer eller mindre framgångsrikt av företrädare för de olika sektorerna. Inom äldreomsorgen har nedskärningarna varit omfattande med påföljden att en medicinsk diagnos $i$ allt högre grad blir utslagsgivande för möjligheten att få insats från hemtjänsten (se t.ex. Andersson 2004). Abbott skulle säkert ha uttryckt det som att ingen genom abstrahering, vare sig till innehåll eller formalisering, kunnat legitimera satsning på de sociala inslagen i omsorgen. Inom omsorgen av funktionshindrade har lagstiftningen skapat struktur på så sätt att rättigheterna kodifierats. Detta är betingelser som personalen måste förhålla sig till. Man kan, med hänvisning till att sjukdom är en viktig motivering till att hemtjänst beviljas, förvänta sig att den medicinska kunskapen blir mera central för äldreomsorgspersonal än för personal som arbetar med funktionshindrade. Man kan också förvänta sig att rättigheterna eller juridiken är mera central 
hos personal som arbetar med funktionshindrade än hos äldreomsorgspersonal.

\section{Kvalitetssäkring genom utbildning?}

Förändringar i kunskapsbasen kan tvinga fram förändringar på flera andra plan, i arbetsuppgifter, $i$ arbetsfördelning och i hierarkisk ordning. Förändringar i omvärlden, till exempel reformer, förändringar i demografi, ekonomi eller lagstiftning, kan också få sådana effekter. Även "strukturell oro", dvs. en påfrestning för personal på verksamhetens alla nivåer, kan vara en faktor som kan påverka. I samband med ett lågt söktryck till gymnasieskolornas vård- och omsorgsprogram (Svenska Kommunförbundet 2003) har många funderingar och farhågor väckts kring organiserandet och utförandet av framtidens omsorgsverksamheter. Debatten bottnar i en oro över kvalitet och tillgänglighet; hur ska omsorgen utformas? vilka ska utföra den? och för vilka den ska finnas till? är frågor som aktualiserats.

Omsorgsforskare har förhållit sig kritiska till tanken på professionalisering. Kunskap är inte neutral menar Wærness (1995). I mötet med praktiken kolliderar olika mål. Följden av en längre formell utbildning kan leda till en mer eller mindre långtgående specialisering och hierarkisering med personalnedskärningar som följd. Arbetsgivare är inte villiga att betala omkostnader och specifika krav som en profession ställer för alla anställda utan endast för den mindre grupp vars specialutbildning behövs (ibid.). Till yttermera visso fjärmar akademisk kunskap de yrkesverksamma från det prak- tiska arbetet och för i stället in dem i andra karriärer, till administration och forskning. Många forskare har sett det som nödvändigt att i stället lyfta fram och plädera för en uppvärdering av kvinnors erfarenhet. Dit hör Wærness $(1984,1999)$ med sitt begrepp "husmoderskompetensen" som hänför sig till vad kvinnor erövrat i familjen som mödrar, döttrar och svärdöttrar. Också Davies (1995) tillhör gruppen som vill lyfta fram den könade kompetensen. Hon menar att i betoningen av byråkratins opersonliga kraft, det rationella, formella och emotionell distans kommer både kreativitet och flexibilitet att gå förlorad. Andra forskare (se t.ex. Astvik 2003 och Johansson 2001) menar att man måste se bortom normativa beskrivningar av kvinnors liv och arbete och istället betona utbildning för omsorgens personalgrupper. Uppfattningen om personalens kompetens kan således sägas befinna sig i en brytpunkt mellan formell utbildning och sunt förnuft (Wreder 2005) där olika yrkesgrupper och forskare förespråkar olika kunskapskrav.

På ett kunskapsteoretiskt plan kan man diskutera vad för slags kunskap som är relevant i ett visst sammanhang och hur den formas. Dewey och Bentley (1950) menar att teori och praktik inte kan behandlas som två skilda element, det handlar snarare om ett förhållningssätt där kunskap ses som både och. De förespråkar med andra ord en dialektisk inställning till kunskap, där individen lär i samspel med sin (föränderliga) omgivning och där det dagliga arbetets vardagskunskaper ses som grunden för ett vetenskapligt förhållningssätt. Genom att stimulera individen till engagemang och betona värdet mellan omgivning, utbildning 
och erfarenhet tillhandahålls kunskap som också blir en förutsättning för aktiv påverkan av individens egen situation (Hartman \& Lundgren 2002).

Uttalandet från Wærness, likaväl som Abbott och Dewey m.fl. om att kunskap inte är neutral kan tolkas som att det beror på sammanhanget om den ska klassificeras som det ena eller det andra. Utifrån ovanstående resonemang blir det intressant att studera hur enhetschefer och personal förhåller sig till kompetenskrav och utbildningsnivå.

\section{Metod och material}

Undersökningen har en kvalitativ ansats och utgörs av två intervjustudier, en med personal och enhetschefer i äldreomsorgen och en med personal och enhetschefer i handikappomsorgen. Studierna genomfördes i två städer och i olika äldre- respektive handikappverksamheter i dessa städer. Undersökningen ingår i ett internationellt projekt och urvalskriterierna har gjorts i samarbetet med övriga deltagande länder. ${ }^{2}$ För en anpassning till detta projekt innebär det bl.a. att äldreomsorgsverksamheter i både kommunal och privat regi är representerade. Studien inom handikappomsorgen vänder sig till personal som arbetar med personer med utvecklingsstörning.

Kontakt med fältet togs i ett första steg med tjänstemän på kommunal nivå. De

2 För mer information angående projektet och dess urvalskriterier se Johansson (2003) och Hansen \& Jensen (2004). informerade i sin tur olika enhetschefer om studien, vilka därefter kontaktades av huvudförfattaren. De som fortfarande var intresserade av studien erhöll mer information och ombads i sin tur informera omsorgspersonalen för att höra sig för om intresse att delta. Datainsamlingen genomfördes inom äldreomsorgen hösten 2002 och inom handikappomsorgen våren 2003.

Totalt har 34 personer som arbetar i det direkta arbetet med äldre och personer med funktionshinder (i fortsättningen kallade "personal«) samt tio enhetschefer intervjuats. I tabellerna nedan presenteras personalen utifrån de verksamheter de arbetar $\mathrm{i}$ samt vilken utbildning de har.

Av Tabell 1 framgår att det är fler personal representerade i studien från äldreomsorgen än handikappomsorgen. Det framgår också att männen är överrepresenterade i materialet sett till antal män som arbetar i omsorgsverksamheterna.

Utbildningsmässigt skiljer sig personalen åt.

Tabell 2 visar att de flesta män inom äldreomsorgen som intervjuats arbetar vid särskilda boenden och är vårdbiträden. Kvinnorna har en mer jämn fördelning mellan $i$ vilka verksamheter de arbetar och i utbildningsnivå.

De personer som arbetar som undersköterskor har antingen gått den kommunala omvårdnadsutbildningen eller en 32 veckors kompletterande utbildning. Vårdbiträdena har en mer skiftande bakgrund med olika gymnasiekompetenser t.ex. social servicelinje och humanistisk linje. Tre personer har gått sjukvårdsbiträdesutbildningen och sex personer har vårdbiträdesutbildning. 
Tabell 1.

Personal inom äldre- och handikappomsorgen, kön och verksamhet.

\begin{tabular}{|l|c|c|c|c|c|}
\hline \multirow{2}{*}{} & \multicolumn{2}{|c|}{ Äldreomsorg } & \multicolumn{2}{c|}{ Handikappomsorg } & \multirow{2}{*}{ Total } \\
\cline { 2 - 6 } & Särskilt boende & Hemtjänst & Boende & D aglig verksamhet & \\
\hline Kvinna & 10 & 8 & 4 & 5 & 27 \\
\hline Man & 4 & 1 & 1 & 1 & 7 \\
\hline Total & 14 & 9 & 5 & 6 & 34 \\
\hline Total & \multicolumn{2}{|c|}{23} & & 11 & 34 \\
\hline
\end{tabular}

\section{Tabell 2.}

Antal vårdbiträden (vb) och undersköterskor (usk) i äldreomsorgen.

\begin{tabular}{|c|c|c|c|c|c|}
\hline & & Hemtjänst & Särskilt boende & Total (kön) & $\begin{array}{c}\text { Total } \\
\text { (usk/vb) }\end{array}$ \\
\hline \multirow[b]{2}{*}{$\mathrm{Vb}$} & kv & 5 & 5 & 10 & \multirow[b]{2}{*}{14} \\
\hline & man & 1 & 3 & 4 & \\
\hline \multirow[b]{2}{*}{ Usk } & kv & 3 & 5 & 8 & \multirow[b]{2}{*}{9} \\
\hline & man & - & 1 & 1 & \\
\hline \multicolumn{2}{|l|}{ Total } & 9 & 14 & 23 & 23 \\
\hline
\end{tabular}

Två personer har studerat vid universitet och andra har grundskolekompetens.

Handikappomsorgens personal är än mer differentierad vad gäller utbildningsbakgrund. Av dem som arbetar inom daglig verksamhet har flertalet av personalen högskoleexamen som arbetsterapeuter och lärare. Andra har gått Grundutbildning för Psykiskt Utvecklingsstörning (GPU) och Påbyggnadsutbildningen (PPU), eller sjukvårdsbiträdesutbildning. Personalen vid boenden har gått GPU och PPU, sjukvårdsbiträdesutbildning och har gymnasie- eller enbart grundskolekompetens.

Tio enhetschefer som arbetar inom de olika verksamheterna har intervjuats, fem kvinnor och en man i äldreomsorgen och tre kvinnor och en man i handikappomsor- gen. Deras bakgrund skiljer sig åt. Flera har ingen erfarenhet av arbetet inom omsorgsverksamheterna innan de blev chefer, andra har en lång erfarenhet, först som vårdare och därefter som chef.

\section{Empiri och analys}

I det som följer presenteras data från intervjuerna med enhetscheferna och personalen. Analysarbetet liknar det som Alvesson och Sköldberg (1994) menar är centralt för en hermeneutisk tolkningsprocess, där man pendlar mellan del och helhet samt mellan förförståelse och förståelse. Analysen genomfördes inledningsvis utifrån vad vi kallar för en naiv läsning, där vi sökt efter 
en helhetsförståelse av materialet men också efter mönster och avvikelser. Den naiva tolkningen syftar till att få förståelse för meningsinnehållet i materialet samt idéer för vidare analyser (Lindblad et al. 2005). I nästa steg har materialet tematiserats, dvs. i samspel med teoretiska utgångspunkter och det som framkommer i intervjuerna har materialet kodats.

De teman vi lokaliserat för enhetscheferna inom handikappomsorgen handlar om strukturella problem som får konsekvenser för verksamheten. De talar om avsaknad av relevant grundutbildning för personalen. Bland enhetscheferna i äldreomsorgen diskuteras formell utbildning kontra personlig lämplighet, dvs. vad som är att föredra för kompetens bland personalen.

Handikappomsorgspersonalen skiljer sig åt utbildningsmässigt. Det avspeglar sig i deras tal om utbildning och kompetens då de talar om vikten att ha dubbelkompetens. Äldreomsorgspersonalen diskuterar samma ämne som sina enhetschefer, formell utbildning kontra personlig lämplighet.

\section{Enhetschefer handikappomsorgen - avsaknad av relevant utbildning}

Under samtalen med enhetscheferna inom handikappomsorgen framkom att samtliga upplever att den utbildning som finns att tillgå för vård- och omsorgspersonal inte är relevant för deras personalgrupper. De efterfrågar en grundutbildning som riktar sig mot funktionshindrade och personer med utvecklingsstörning. De menar att omvårdnadsprogrammet som ges idag på gymnasienivå inte är lika inriktad på deras målgrupper som de tidigare utbildningarna, GPU och PPU var. ${ }^{3}$ Detta medför att det är svårt att rekrytera personal som är utbildad inom området. Det leder till att personal som varit med länge undervisar nyanställda, vilket inte ses som önskvärt då enhetscheferna är överens om att det är viktigt med en för brukargrupperna relevant utbildning. De svårigheter som lyfts fram har främst att göra med bemötandefrågor, $d v s$. att personal utan utbildning har stora svårigheter att hantera problematiska situationer $i$ arbete, exempelvis då hot och våld förekommer. Hela personalgrupper behöver också höja sin kompetensnivå menar de, bl.a. utifrån att det idag finns fler brukargrupper inom den sociala omsorgen och mer kunskap om olika funktionshinder. De betonar särskilt åldrande och demens samt sex och samlevnadsfrågor.

Vi menar att den utbildning som finns att tillgå saknar legitimitet hos enhetscheferna. Utbildningen tillhandahåller inte den kompetens som enhetscheferna anser är relevant för personalen inom handikappomsorgen. Samtidigt framhåller de att utbildning är något centralt för all personal eftersom det finns föreställningar om utvecklingstörning och hur utvecklingsstörda personer är, föreställningar som de menar inte stämmer överens med den verklighet personalen sedan möter i arbetet. I enighet med

3 För en utförlig beskrivning av omvårdnadsprogrammet samt en diskussion kring enhetschefers och omsorgspersonals utbildning se Törnquist (2004). 
Abbotts (1988) resonemang om abstrakt och konkret kunskapsinnehåll, menar vi att handikappomsorgens enhetschefer eftersträvar en balans vad gäller relationen mellan formell utbildning och konkret, icke generaliserbar, kunskap. De är medvetna om att arbetet kräver generell kunskap om ett avgränsat område; funktionshinder och dess konsekvenser för brukargruppen och personalen. Denna generella kunskap är något de gärna ser att personalen har med sig in i en anställning.

\section{Enhetschefer äldreomsorgen - formell utbildning kontra personlig lämplighet}

Enhetscheferna inom äldreomsorgen önskar att all omsorgspersonal ska ha formell utbildning inom vård och omsorg, helst undersköterskeutbildning. Men det finns samtidigt en framträdande diskussion bland enhetscheferna om vad för kompetens som är att föredra, och det är inte självklart att undersköterskekompetens är det enda alternativet. Det är tydligt att personlig kompetens i mångt och mycket väger tyngre än formell utbildning när de ska rekrytera personal (jmf Törnquist 2004). De framhåller att om de har att välja mellan att rekrytera en person med undersköterskeutbildning och en person utan formell utbildning som anses ha bättre personlig lämplighet, får den senare anställningen. Med personlig lämplighet menas att vara empatisk, lyssna in och känna av stämningen hos den äldre. Vissa enhetschefer framhåller att de inte alls söker efter personal med formell utbildning utan har andra kriterier för vad som utgör relevant kompetens för omsorgspersonal, t.ex. att personalen inte ska vara för ung. Helst rekryteras kvinnor över 30 år, då erfarenhet och engagemang för arbetet betonas. Andra enhetschefer för fram att de gärna ser att män och invandrare söker anställning då man vill ha en mångfacetterad personalgrupp. Att ha utbildning som undersköterska anses av dem inte relevant då det är primärvården som ska tillhandahålla den vård som krävs.

Andra chefer har andra strategier för personalens kompetensutveckling. En chef inom särskilt boende betonar vikten av att vidareutbildningen sker i nära anslutning till personalens behov, dvs. utbilda dem i pedagogiska metoder som de har användning för i sitt dagliga arbete, i det här fallet utbildning i reminiscensmetoden. ${ }^{4}$

Det framgår således att enhetscheferna inte tar det för självklart att all personal ska ha undersköterskekompetens. De poängterar istället vad Wærness (1984, 1999) kallar för husmorskompetens, dvs. personliga egenskaper och erfarenheter av arbetsuppgifter som traditionellt setts som kvinnors sysslor. Den medicinska kompetensen anses andra yrkesgrupper kunna tillhandahålla, t.ex. primärvårdens personal. Istället nämns andra alternativ för kompetensutveckling, pedagogiska metoder som ska underlätta arbetet för personalen och förbättra situationen för människor med demens. I relation till de nationella målen som satts upp för omsorgspersonal vad gäller utbildning tycks det som att enhets-

4 Reminiscensmetoden är en pedagogisk modell med fokus på att hjälpa personer med demens att kommunicera (Arntzen 2005). 
cheferna inom äldreomsorgen inte förhåller sig helt kritiska till idén om att alla ska ha undersköterskekompetens. Men i det praktiska arbetet med att rekrytera personal saknar utbildningen legitimitet då det inte är den kompetens som prioriteras. Enhetschefernas önskan om utbildad personal överskuggas av vikten att personalen mest av allt har de egenskaper som anses passa in $\mathrm{i}$ äldreomsorgens verksamhet. Abbott (1988) menar att legitimitet uppstår då det finns en överensstämmelse mellan talet om kunskap och de konkreta handlingarna, vilket verkar saknas hos enhetscheferna i äldreomsorgen.

\section{Personal inom handikappomsorgen - dubbelkompetens}

Personalen inom handikappomsorgen ger i intervjuerna uttryck för att det är viktigt med utbildning för att kunna utföra ett bra arbete. De flesta anser inte att den kommunala gymnasieskolans omvårdnadsprogram fokuserar tillräckligt mycket på handikappfrågor men de tycker att det är bra med en grundläggande formell utbildning, dvs. att ha kunskap om olika handikapp och dess konsekvenser för brukarna.

Det är klart du måste ju ha omvårdnadsutbildningen. För dom har ju ofta olika tillläggshandikapp. Två utav tjejerna har Downs och har hjärtfel. Och en utav dom fick ett häftigt blodtrycksfall. Hon blev alldeles blå om läpparna. Då kommer dom här medicinska kunskaperna fram. Och att man är lugn och inte skärrar upp sig. För $i$ och med att jag är lugn då är det inte lika hemskt när hela världen snurrar. (Kvinna, daglig verksamhet, vårdarinna)

Samtidigt som utbildning förespråkas betonas också vikten av personlig lämplighet samt att man lär sig via erfarenhet, genom att arbeta i verksamheterna. Det hör samman med att det är viktigt att lära sig hur varje enskild brukare vill ha det, vad brukarnas behov är och att det i sin tur påverkar vad för kompetens som är relevant för personalen.

Kan du teckenspråk?

Jag kan inte till fullt, jag fick lära mig när jag började här. Och jag klarar mig bra tillsammans med Annika (brukaren).(...) utbildning är ju jättebra i botten. Det tycker jag absolut. Men såär det så många andra såna här egenskaper tycker jag. Du måste ha empati och du måste kunna samarbeta också. (Man, boende, vårdare)

Denna dubbelhet, att förespråka både formell utbildning och erfarenhetsbaserad sådan, kan även ses i ljuset av att personalen skiljer sig utbildningsmässigt åt och att de menar att det är en fördel att ha skilda kompetenser.

Det är många som är duktiga på olika områden, många som verkligen tillför någonting, det är roligt med så blandad personal, många har ju dubbelkompetens, vårdareutbildningar och konstnärliga utbildningar. (Kvinna, daglig verksamhet, arbetsterapeut)

Det lyfts fram som positivt att det bland 
personalen finns en mångfald vad gäller kompetens och kunskapsfrågor, att det berikar och är positivt, både för personalen och för brukarna i de olika verksamheterna.

Förmåga att se och förstå individens behov, tillsammans med formell utbildning inriktad på målgruppen, är vad handikappomsorgens personal framställer som centrala kompetenskrav. Att kunna bidra med olika kompetenser framställs som positivt, hur man förvärvar dessa kompetenser verkar å andra sidan vara av underordnad betydelse. Det är viktigt att vara medveten om att brukarnas behov skiljer sig åt samt att kunna konkretisera sina kunskaper och förstå enskilda individer.

\section{Personal inom äldreomsorgen-formell utbildning kontra personlig lämplighet}

På frågan om den formella utbildningens betydelse och vad för kompetens som är relevant inom äldreomsorgen framkom att ett tydligt tema har att göra med vem som är bäst lämpad att sörja för vård och omsorg till äldre människor. Det är en aktuell frågeställning som uppmärksammats i flera studier (se t.ex. Törnquist 2004, Wreder 2005). Medan Socialstyrelsen (2004) förespråkar en allmän höjning av kompetensnivån är diskussionen bland personalgruppen mer disparat. Frågan handlar om huruvida man behöver ha undersköterskekompetens eller inte för att göra ett bra jobb inom äldreomsorgen. I det empiriska materialet framkommer att en del, både undersköterskor och vårdbiträden, menar att man inte behöver vara undersköterska då man ändå inte får utföra sådana arbetsuppgifter i sitt arbete. Andra, också både undersköterskor och vårdbiträden, menar att det är högst relevant att ha en undersköterskeutbildning för att kunna göra ett bra arbete.

De personer som för fram att man inte behöver vara undersköterska hänvisar till avsaknad av uppgifter som är av medicinsk karaktär. De saknar möjligheten att få ge sprutor, lägga dosetter, lägga om sår etc. Indirekt är de kritiska till den verksamhet de arbetar i som inte làter utbildad personal utföra medicinska uppgifter och ser ingen nytta av att i framtiden utbilda sig till undersköterska eller att arbeta kvar i äldreomsorgen.

Jag är undersköterska och jag tycker att som undersköterska fär man inte ut så mycket av ett sånt här ställe, det är inga såromläggningar, ingenting sånt, så det kan bli lite tråkigt, man känner att efter ett år vill man kanske härifrån för man vill göra lite mer. (Kvinna, usk, särskilt boende)

Det handlar ju mycket om en inställning menar jag. Det är ju liksom flit och arbetsmoral och att man är trevlig mot domboende och har tålamod. (...) Det är lite självbedrägeri i den här branschen. Man ska låtsas att det finns en utvecklingsväg, en karriärväg. Det är klart som vårdbiträde kan man bli undersköterska. Men undersköterskor gör ofta exakt samma saker som vårdbiträden $i$ äldrevården. (Man, vb, särskilt boende)

Ovanstående citat speglar en frustration som flera av intervjupersonerna gav uttryck för, att som undersköterska inte få utföra 
uppgifter man är kompetent för och att man därför tycker att arbetet inte är utvecklande. Att utbilda sig till undersköterska ses inte heller som nödvändigt då man inte får nyttja den kunskap man har och man gör ändå samma saker som vårdbiträdena. Det har visat sig att de som tar examen från omvårdnadsprogrammet tenderar att värdera de medicinska kunskaperna högre än annat de lär sig under utbildningen (SOU 1997:170).

De personer som i sin tur menar att det är nödvändigt att ha undersköterskekompetens framhåller andra aspekter av sitt arbete, att man genom utbildning förstår de äldres kroppar och humör bättre och får på så sätt ett annat seende angående vad friskt åldrande och vad som räknas som sjukt.

Vanlig sjukvårdskunskap, givetvis är det viktigt. Sen ska du ha en stor portion tålamod. Du ska ha en stor portion fantasi. Det är det viktigaste. (skratt) Som undersköterska är det ju både sjukvård och omvårdnad. Här blir ju den större delen omvårdnad men jag behöver ju ändå det andra. (Kvinna, usk, särskilt boende)

Dessa personer för fram att det är viktigt med både undersköterskekompetens, dvs. att man har kunskap om omvårdnad och sjukvårdskunskaper, och personlig lämplighet, dvs. humor och fantasi. De ser ingen motsättning mellan de olika kompetenserna. Franssén (1997) och Wreder (2005) menar att det pågår en kamp mellan vårdbiträden och undersköterskor i äldreomsorgen angående vem som ska utföra olika arbetsuppgifter där undersköterskorna försöker upprätthålla en gräns mellan sig och vårdbiträdena och försöker på så sätt framhålla sin kompetens.

Vi menar utifrån vår analys att argumenten för eller emot formell utbildning också bottnar i olika förståelse av vad som menas med att ha en undersköterskekompetens samt vad man tillåts göra inom ramarna för den verksamhet man arbetar i. Den yrkeskunskap som följer med omvårdnadsutbildningen leder till att många av undersköterskorna frustreras av att inte få utföra en viss typ av arbetsuppgifter, de förväntningar de har på sitt yrkesliv införlivas inte inom äldreomsorgen. Många har med andra ord en begränsad syn på vad det är en undersköterska ska utföra och inkluderar inte andra delar än de medicinskt inriktade i sitt arbete. Vi menar att personalen och enhetscheferna har en snäv syn på vad för kunskap som omvårdnadsutbildningen genererar. Balans saknas i synen på hur den generella kunskapen ska kunna konkretiseras respektive hur den konkreta kunskapen ska tas till vara. Utifrån Abbotts (1988) terminologi innebär inskränkningen i möjligheten att utföra undersköterskeuppgifter att undersköterskorna ser en degradering av sin kunskap. Att det inte lönar sig att utbilda sig innebär att vem som helst kan utföra arbetet inom äldreomsorgen.

\section{Diskussion}

Syftet med artikeln är att undersöka hur enhetschefer och personal vid två äldreoch handikappomsorgsverksamheter förhåller sig till utbildning och kompetensfrågor. Våra resultat kan inte generaliseras till att gälla all omsorgspersonal eller alla enhets- 
chefer men då vi genomfört intervjuer i två olika städer och vid olika omsorgsverksamheter, pekar materialet mot en rad centrala aspekter gällande utbildning och kompetensfrågor. Från nationell nivå påtalas att omsorgspersonal bör ha minst undersköterskekompetens. Ändå kan vi ur det empiriska materialet se att omvårdnadsutbildningen saknar legitimitet bland flertalet aktörer som ingår i urvalet. Det finns ingen koppling mellan den kunskapsbas som undersköterskan ser som central och den prioritering av arbetsuppgifter som sker i omsorgspraktiken. Den kunskap som det omgivande samhället ser som legitim avvisas på arbetsplatsen. Legitimitetsproblematiken finns alltså på arbetsplatsen, inte på den offentliga arenan. Vi ska med utgångspunkt i Abbotts och Deweys teorier om kunskap och kompetens diskutera hur man kan förstå personalens sätt att förhålla sig till utbildnings- och kompetensfrågorna.

De flesta bland den intervjuade personalen instämmer $\mathrm{i}$ att undersköterskans kompetens inte kommer till användning inom äldreomsorgen. Arbetet handlar om andra saker än att utföra medicinskt relaterade sysslor, menar de. På liknande sätt kan enhetschefernas förhållningssätt till vad som utgör relevant kompetens för äldreomsorgens personal sägas sakna den balans som Abbott (1988) förespråkar vad gäller kunskapens funktion. Enhetscheferna inom handikappomsorgen betonar vikten av utbildning men menar att omvårdnadsutbildningen inte ger personalen den rätta kompetensen. Även här kan vi se att den formalisering av grund för anställning från centralt håll slår fel då den utbildning som förespråkas inte anses leda till relevant kompe- tens. Yrkeskunskapen korresponderar inte med centrala värden på arbetsplatsen, och yrkesgruppen försvagas i Abbotts mening.

Satsningen på att omsorgspersonal ska ha undersköterskekompetens har inte lett till en balans mellan olika aktörers önskemål, dvs. de kompetenskrav som förordas från centralt håll saknar täckning för hur aktörer på det lokala utförarplanet kan se på vad som är relevant kompetens. Men som vi visat finns det också personal inom äldreomsorgen som framhäver nyttan av andra kunskaper än enbart de medicinska, vilka också förvärvats genom undersköterskeutbildningen. De menar att äldreomsorgens brukare är i behov av att personalen har bred kompetens och förespråkar både konkreta vårdspecifika kunskaper men också vad som kallas för personliga egenskaper. De argumenterar på liknande sätt som personalen inom handikappomsorgen, vilka diskuterar kompetensfrågan utifrån vikten av att få kunskap i närhet till brukaren. Utifrån Deweys och Bentleys (1950) resonemang kring kunskap och pedagogik skulle man kunna argumentera för att det är lika relevant för omsorgspersonal att förhålla sig till både teoretisk kunskap om vård och medicin som det är att ta in brukarnära kunskap om de individer man arbetar tillsammans med. Ett dialektiskt förhållningssätt till kunskap i relation till omsorgsuppgifter rymmer inte enbart husmorskompetens som utgår från kön och erfarenhet från hemliknande arbetsuppgifter. Inte heller förespråkas enbart ett medicinskt förhållningssätt där det centrala är att få utföra medicinska sysslor. Istället handlar det om att ta vara på olika kunskaper och få möjlighet att använda sin kompetens i relation till 
den brukargrupp man arbetar för. Genom att se nyttan av olika kompetenser, istället för att fokusera på avsaknad av relevanta arbetsuppgifter, betonas en mångfald och en vidgad syn på vad för kunskap som är relevant. Utifrån ovanstående resonemang identifierar vi två aspekter som kan komma att aktualiseras inom framtidens omsorgsverksamheter.

Formaliseringsfällan. Den ena aspekten har att göra med en alltför stark formalisering som beror på processer som genereras från en nationell nivå. Formaliseringen består i att vissa mål och insatser angående utbildning och kompetens avser en politisk strävan snarare än faktiska behov.

Tomhetsfällan. När en alltför stark formalisering, som den ovan beskrivna, blir realitet, får detta konsekvenser på ett lokalt plan. Om personalens kompetenser uttrycks i allt för abstrakta termer (avsaknad av innehåll) och att de kompetenser som förespråkas på nationell nivå saknar legitimitet i verksamheterna, uppstår ett glapp i hur olika aktörer förhåller sig till kompetenskraven. Som vi visat i artikeln finns det olika åsikter om vilken kunskap som är mest relevant för personalen inom äldre- och handikappomsorgen, där de nationella målen inte alltid stämmer överens med vad aktörerna på lokal nivå för fram som centrala. De inom äldreomsorgen som menar att de frustreras av att inte få utföra medicinska uppgifter, uttrycker en sida av denna helhet. De har en utbildning som gör att de är lämpade för vissa arbetsuppgifter men som de i verksamheten inte får utföra. Detta leder till att de osynliggörs i sitt kunnande.

Frågan vi ställer oss utifrån detta är vad aktörerna på nationell nivå har för intentioner med att höja utbildningsnivån och att formalisera all kompetens kring en utbildning? Handlar det enbart om att säkra återväxten och kvaliteten inom omsorgsverksamheterna eller ser de även andra vinster med att personalen vidareutbildas? Vilka intentionerna än är menar vi att utbildning och kompetensutveckling är av största vikt för omsorgens aktörer på lokal nivå. Det måste, och här lutar vi oss återigen mot Abbotts betoning av arbetsplatsen som den centrala arenan för utveckling, föras vidare diskussioner om vilken kompetens som är mest relevant för brukargrupperna och för personalen. Om den yrkeskompetens som på central nivå förespråkas för att stärka yrkena och återväxten av omsorgspersonal, saknar legitimitet i de berörda verksamheterna menar vi, med utgångspunkt i Abbotts teori, att det snarare kan bli fråga om en utarmning av omsorgsarbetet än en kvalitetshöjning. Frågan är vad omvårdnadsutbildningen saknar i sin konkretisering av centrala yrkesaspekter? Ett fåtal förespråkar ändå att undersköterskekompetens är relevant för att arbeta inom äldreomsorgen. Hur ska detta förstås? Och hur ska vi förstå handikappomsorgens personal som förespråkar att en mångfald av kompetenser är till gagn för brukargrupperna? Ett behov finns att vidare diskutera vad som är relevant kompetens för personal inom äldre- och handikappomsorgen. Det finns anledning att också diskutera andra kunskapstraditioner än medicinsk och social kompetens t.ex. pedagogiska metoder. I större utsträckning bör brukargruppernas behov och preferenser synliggöras. Det är de som sist och slutligen ger kunskapsbasen legitimitet. 


\section{Referenser}

Abbott, Andrew (1988) The system of Professions. Chicago: The University of Chicago Press.

Alvesson, Mats \& Sköldberg, Kaj (1994) Tolkning och reflektion. Lund: Studentlitteratur.

Andersson, Katarina (2004) "Det gäller att hushålla med kommunens resurser. Biståndsbedömares syn på äldres sociala resurser", Socialvetenskaplig tidskrift. Vol.11 nr 3-4, s. 275-292.

Arntzen, Eva (2005) Kommunikationsmodeller $i$ mötet med personer med demens. Vårdalinstitutets tematiska rum: Demens. www.vardalinstitutet.net

Astvik, Wanja (2003) Relationer som arbete. Akad. avh. Arbetslivsinstitutet.

Christensen, Karen (1997) Omsorg og arbete. Akad.avh. Bergen: Bergens universitet, sosiologisk institutt.

Davies, Celia (1995) Gender and the professional predicament in nursing. Buckingham: Open University Press.

Dewey, John \& Bentley, Arthur F. (1950) Knowing and the known. Boston: Beacon Press.

Drugge, Christina (2003) Omsorgsinriktat lärande. Akad.avh. Luleå: Luleå tekniska universitet, institutionen för lärarutbildning.

Franssén, Agneta (1997) Omsorg i tanke och handling. Akad.avh. Lund: Arkiv förlag.

Hansen, Helle. \& Jensen, Jytte (2004) Work with Adults with Severe Disabilities: A Case Study of Denmark, The Nederlands and Sweden. www. ioe.ac.uk/tcru/carework.htm

Hartman, Sven G \& Lundgren, Ulf P (2002) Individ, skola och samhälle. Stockholm: Natur och Kultur.

Johansson, Stina (2001) Den sociala omsorgens akademisering. Stockholm: Liber förlag.

Johansson, Stina (2003) Work with elderly people. A Case Study of Sweden, Spain and England with additional material from Hungary. www.ioe. ac.uk/tcru/carework.htm

Kommunalarbetaren (2006) »Hon lovar satsa på personalen", Kommunalarbetaren, Nr 32006.

Lindblad Britt-Marie, Rasmussen Birgit H \& Sandman Per-Olov (2005) "Being Invigorated in
Parenthood: Parents` Experiences of Being Supported by Professionals When Having a Disabled Child", Journal of Pediatric Nursing Vol 20, No 4, s. 288-297.

Mallander, Ove (1999) De hjälper oss till rätta. Akad.avh. Lund: Lunds universitet, institutionen för socialt arbete.

Olin, Elisabeth (2003) Uppbrott och förändring. Akad.avh. Göteborg: Göteborgs universitet, institutionen för socialt arbete.

Regeringens proposition 2005/06:115 Nationell utvecklingsplan för vård och omsorg om äldre.

S 2004:10 Kompetensstegen. Kvalitets och kompetensutveckling $i$ vård och omsorg om äldre. (2004) Regeringskansliet. www.kompetensstegen.se

Sauer, Lennart (2004) Teater och utvecklingsstörning. Akad.avh. Umeå: Umeå universitet, institutionen för socialt arbete.

Socialstyrelsen (2001) Nationell handlingsplan för äldrepolitiken. Lägesrapport 2001. Art.nr. 2001-103-7.

Socialstyrelsen (2002) Kompetenskrav för personal inom vård och omsorg om äldre. Art.nr 2002124-14.

Socialstyrelsen (2004) Investera Nu! Handlingsplan för kompetensförsörjning inom vård och omsorg. Art.nr: 2004-103-10.

Socialstyrelsen (2005a) Personlig assistent. En inventering av forskningsläget. Art.nr: 2005123-27.

Socialstyrelsen (2005b) Omvårdnadsassistentens kompetens. Grundläggande kompetensnivå. Remissversion. Art.nr: 2005-110-8.

SOU (1997) Brister i omsorg. Socialdepartementet 1997:51.

SOU (1997) Bemötandet av äldre. Socialdepartementet 1997:170.

Svenska kommunförbundet (2003) Aktuellt om äldreomsorgen.

Törnquist, Agneta (2004) Vad man ska kunna och hur man ska vara. Akad.avh. Stockholm: Lärarhögskolan i Stockholm, institutionen för samhälle, kultur och lärande. 
Wahlgren, Ingela (1996) Vem tröstar Ruth? Akad. avh. Stockholm: Stockholms universitet, School of Business.

Wreder, Malin (2005) I omsorgens namn. Akad. avh. Karlstad: Karlstad universitet, institutionen för samhällsvetenskap, avdelningen för sociologi.

Wærness, Kari (1984) "The rationality of caring", Economic and Industrial Democracy. Nr. 5, s. 185-211.
Wærness, Kari (1995) „En offentlig tjeneste i spenningsfeltet mellom ulike kulturer". I Stina Johansson (red.) Sjukhus som hem och arbetsplats: omsorgsyrken i Norge, Sverige och Finland. Stockholm: Bonniers utbildning; Oslo: Universitetsforlaget.

Wærness, Kari (1999) „Et personalperspektiv på eldreomsorgen i den senmoderne skandinaviske velferdsstat". I 2000-talets äldrevård och äldreomsorg. Spri rapport nr: 491.

\section{Summary}

\section{Upper secondary health care programme as means or measure? On the problem of legitimacy and view of knowledge}

Due to a low rate of qualification from training programmes for auxiliary nurses, demographic changes and retirement of care workers, the competence of care workers is a current issue in Sweden. A need to increase care workers' level of competence and quality in these fields have been made visible. A governmental goal is that all care workers should have auxiliary nurse competence. The purpose of this article is to analyse the arguments of managers and personnel in elderly care and disability about the education and competence of care workers.

Our results show that, among the managers, the present education lacks legitimacy. Managers in disability services say that an education as auxiliary nurse is not relevant for their personnel and that the education is not a foundation for recruitment. The managers in elderly care say that they wish their personnel had this education, but when it comes to recruiting staff they are more concerned about personal competence. That is, they want the staff to have empathy, to be committed, and aware of the needs of the elderly. Opinions among the care workers are more disparate. Most of them do not think that formal training as auxiliary nurse is needed to work in the elderly care. They talked about medical assignments that they had the competence to do but were not allowed to do. The personnel in the disability field share the same opinion as their managers, stating that the available education is not suitable for their needs.

We believe it to be important to make visible the need for competence in care work, and we argue for a broad discussion of care workers' education. If the opinions of actors on different levels differ too widely, that is, if the demand from a central level for vocational training, with the intention of giving the occupation higher status and securing the regrowth of care workers, lacks legitimacy among the practitioners, we think that it could more likely impoverish than increase quality. 